Journal of Southeast Asian

\title{
Appendix I:Focus Group Summary of the Southeast Asian Student Organization
}

\author{
Hanum Tyagita \\ Ohio University, tyagita.hanum@gmail.com \\ Katherine Bruhn \\ Ohio University, katiebruhn@gmail.com
}

Follow this and additional works at: https://docs.lib.purdue.edu/jsaaea

\section{Recommended Citation}

Tyagita, Hanum and Bruhn, Katherine (2011) "Appendix I:Focus Group Summary of the Southeast Asian Student Organization," Journal of Southeast Asian American Education and Advancement: Vol. 6 : Iss. 1, Article 10.

DOI: $10.7771 / 2153-8999.1026$

Available at: https://docs.lib.purdue.edu/jsaaea/vol6/iss1/10

This document has been made available through Purdue e-Pubs, a service of the Purdue University Libraries. Please contact epubs@purdue.edu for additional information.

This is an Open Access journal. This means that it uses a funding model that does not charge readers or their institutions for access. Readers may freely read, download, copy, distribute, print, search, or link to the full texts of articles. This journal is covered under the CC BY-NC-ND license. 


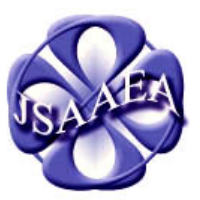

Volume 6 (2011)
Journal of Southeast Asian American

Education \& Advancement

WWw.JSAAEA.org
A peer-reviewed

scholarly journal

published by the

National Association

for the Education \&

Advancement of

Cambodian, Laotian,

and Vietnamese

Americans (NAFEA)

\title{
Southeast Asian American Education 35 Years After Initial Resettlement: Research Report and Policy Recommendations
}

Conference Report of the National Association for the Education and Advancement of Cambodian, Laotian, and Vietnamese Americans

\begin{abstract}
APPENDIX I
Focus Group Summary of the Southeast Asian Student Organization

\author{
Hanum Tyagita and Katherine Bruhn \\ Ohio University
}

\section{Southeast Asian Student Education (K-12): Access, Assessment, and Accountability}

1. How often did you have opportunities to learn about SEA history or culture in school? -Never

2. Did you have any SEA friends or classmates who dropped out of school or who didn't graduate due to state tests?

-One group participant - Laotian American who commented his pursuit of higher education is largely self-initiated - commented his younger siblings are not doing well and want to drop out of school

\section{Availability of ESL programs?}

-Cambodian American student - when arrived in America from Cambodia no true ESL programs available in Boston schools. At first in school district with large Cambodian population ESL was taught by Cambodian teacher who usually used Khmer. When moved to Cambridge, no resources available.

\section{Southeast Asian Language and Culture Programs}

1. How well can you speak, read and write your SEA language?

\footnotetext{
@ SORERIIGHISRESERVED Readers are free to copy, display, and distribute this article, as long as the work is attributed to the author(s) and the Journal of Southeast Asian American Education \& Advancement, it is distributed for noncommercial purposes only, and no alteration or transformation is made in the work. More details of this Creative Commons license are available at $\mathrm{http}: / /$ creativecommons.org/licenses/by-nc-nd/3.0/. All other uses must be approved by the author(s) or JSAAEA.
} 
-Laotian American Student

Cannot speak, read, or write; father spoke to him in Lao but he never understood or was forced to understand.

-Cambodian American Student

Speaks Khmer fluently, spoken at home since she was a child

2. Do we need more SEA language programs in schools and the community?

-Overall consensus - yes

-The community must be made more aware of this region and its languages.

-In making more aware, negative myths and stereotypes can be eliminated.

3. Does our college have classes in our SEA language?

Yes

How popular are they?

-Not too popular

-However, in the experience of the three native Indonesian language teachers involved in our discussion group, the programs at Ohio University are more popular than at Columbia, Arizona State University, and Michigan State University where they previously taught.

Who has taken these classes?

-Mostly non-native speakers

Are they geared more towards non-native speakers or native speakers?

-Non-native speakers

What could be done to improve these courses?

-Find a way to make them more attractive to students in order to increase the number of students in classes

4. What policy changes could be made at the local, state, or federal levels to help us address these SEA program issues?

-More funding or emphasis on these languages so that students can begin learning about them earlier than university - making it possible and feasible for high schools to introduce these languages

\section{Southeast Asian American Higher Education Access and Opportunities}

1. What Challenges and obstacles did you face in getting into college?

Laotian American Student:

-As first generation student, little support from parents

-Parents did not understand the importance of college or the process of application. -Because little stress was placed on the importance of college parents did not foster a strong desire and motivation to go to college. 
Cambodian American Student:

-More support from parents in regards to their understanding of the importance of higher education. However, it is difficult as they did not understand the application process.

2. What challenges and obstacles are faced by other SEA students', which prevent them from getting into college?

Overall consensus:

-Lack of support from family

-Lack of support from high school

3. How much support did you receive from your parents and others to get into and stay in college?

Laotian American Student:

-Little support - self initiated process

-Even now parents don't understand strong desire to continue education

Cambodian American Student

-Felt she received ok support

-More support from the community where she lived in Cambridge, MA

4. What challenges do SEA students face in college?

-Many SEA students, particularly in experience of Texas (Laotian American student), attend community college - here there are not necessarily the proper support structures or motivation.

5. What policy changes could be made at the local, state, or federal levels to help us address these higher education issues?

-Requirements in high schools for ALL students to learn about things like FAFSA and opportunities available in order to encourage and motivate the process of applying to college - making it seem possible to them

\section{Southeast Asian American Communities}

1. What are some of the biggest challenges facing our SEA community?

-Not a strong desire to maintain traditional culture

-Individuals moving away from their cultures wanting to assimilate into American society

2. Do members of SEA communities where you have lived experience racial or ethnic discrimination?

-Overall consensus no

-Particularly in the academic environment of Athens, Ohio individuals felt that people are generally very accepting

-However individuals did comment that often they find non-SEA communities in America to be closed off or not interested in forming relationships - leading to 
discussion of cultural differences and often American's lack of knowledge or fear to interact with foreigners.

3. What things can be done to overcome any challenges faced by SEA communities?

-Educate the greater American public about SEA

-Provide more education in schools regarding SEA history and culture so that Americans are aware of this community and region of the world

\section{About the Authors}

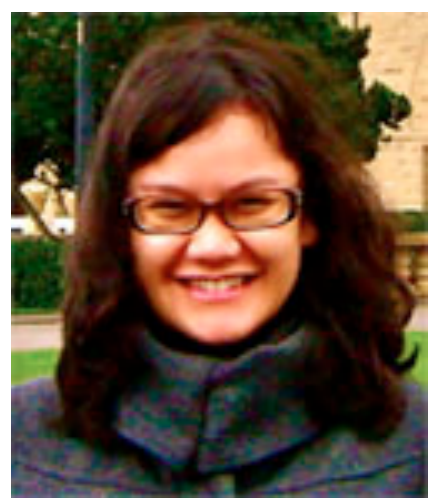

Born in Jakarta, Indonesia, Hanum Tyagita earned her Bachelor's degree in Teaching English as Foreign Language from Universitas Katolik Indonesia Atma Jaya in Jakarta. Hanum has taught both English and Indonesian. Her students included those in preschool, corporate industries, and foreign diplomats. In 2008, Hanum was awarded the Fulbright Foreign Language Teaching Assistant scholarship to teach Indonesian at Columbia University. Presently, she is now pursuing her Master's degree in Southeast Asian Studies at Ohio University, focusing on the decline and adaptation of local language in Indonesia, Singapore and Malaysia. She hopes to be able to pursue her Ph.D. in the Netherlands one day and to return ultimately to Indonesia to help the Ministry of Education develop an adequate language curriculum and methodology in elementary schools.

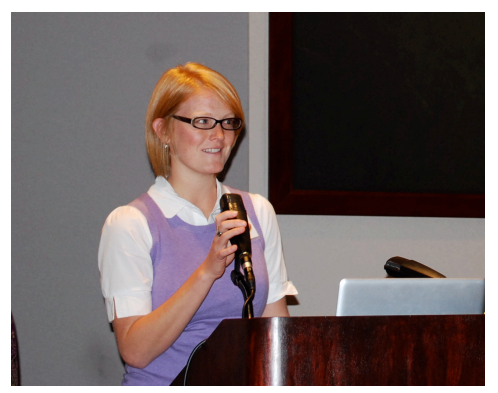

Katherine Bruhn is currently a first year of master's student at Ohio University in the department of Southeast Asian Studies. After spending 17 months over the course of two years in Indonesia, as a Fulbright English Teaching Assistant in West Sulawesi and an English Teacher at Gadjah Mada University's International Consortium for Religious Studies (ICRS), she returned to Ohio where she is originally from to learn more intensively about the region of Southeast Asia and Indonesia. Her current research interests involve religious education in Indonesian secular high schools, violence and conflict, interfaith dialogue in Indonesian schools, youth culture, and the influence of media on youth and their perceptions of diversity and globalization. Upon the completion of her master's degree she hopes to return to Southeast Asia to continue working in this region before eventually pursuing a Ph.D. in Anthropology focused on the study of education in Southeast Asia. 